\title{
Paul Erdös: o Ahasverus da matemática ${ }^{1}$
}

Jacques Fux $x^{2}$

\author{
A vida me fez de vez em quando pertencer, \\ como se fosse para me dar a medida do que eu perco não pertencendo. \\ E então eu soube: pertencer é viver. \\ Experimentei-o com a sede de quem está no deserto \\ e bebe sôfrego os últimos goles de água de um cantil. \\ $E$ depois a sede volta e é no deserto mesmo que caminho.
}

Clarice Lispector

Resumo: Este texto tem como objetivo reconstruir ficcionalmente a vida do matemático Paul Erdös. Partindo do personagem literário Ahasverus - O Judeu Errante - o presente ensaio deseja mostrar as nuances, descobertas e romances desse incrível matemático.

Palavras-chave: Paul Erdös; Matemática; Ahasverus; Teoremas.

\section{Paul Erdös: Mathematician's Ahasverus}

\begin{abstract}
This text intends to construct fictionally the life of the mathematician Paul Erdos. Starting from the literary character Ahasverus - The Wandering Jew - this document shows the nuances, discoveries and the stories of this amazing mathematician.
\end{abstract}

Keywords: Paul Erdös; Mathematics; Ahasverus; Theorems.

1.

Foram quase vinte nove horas de trabalho de parto. A criança estava numa posição muito difícil de sair. Talvez ela já vislumbrasse as mazelas, os milhares de problemas, e as poucas soluções que a vida ofereceria. Mas os pais queriam muito que essa criança vingasse. Que ela fosse feliz e que os presenteasse futuramente com muitos descendentes. Além disso, desejavam que fosse um menino para perpetuar o novo sobrenome húngaro que a família adotara. Antes usavam o nome judeu Engländer, que nunca fora bem visto, e que teve que ser devidamente esquecido e apagado,

1 Apesar das referências biográficas, esta é uma obra de ficção e não tem compromisso com a 'realidade'.

2 Vencedor do Prêmio São Paulo de Literatura 2013 com o livro Antiterapias e Vencedor do Prêmio CAPES de Melhor Tese de Letras/Linguística do Brasil em 2011 com o livro Literatura e Matemática: Jorge Luis Borges, Georges Perec e o OULIPO. Pesquisador Visitante na Universidade de Harvard (2012-2014), pós-doutor em Teoria Literária pela Unicamp e pós-doutorando em Literatura Comparada pela UFMG. Doutor em Literatura Comparada e Doutor em Língua, Literatura e Civilização Francesa (UFMG/Lille 3). Graduado em Matemática e Mestre em Ciência da Computação pela UFMG. Acaba de lançar seu novo romance Brochadas (Menção Honrosa no Prêmio Cidade de Belo Horizonte) pela Editora Rocco. 
como uma proposição estúpida e incoerente. Agora eles abraçavam e assimilavam uma nova e abastada cultura através do nome Erdös, “da floresta”. E lá imaginavam encontrar a paz, a serenidade e a aceitação que tanto sonhavam. Um absoluto engano, como a História comprovaria. Eles ainda tinham duas lindas filhas, que amavam bastante, e esperavam que essa nova criança completasse, com alegria, a saudável família.

Finalmente a criança veio ao mundo no dia 26 de março de 1913. E para felicidade de todos nasceu um menino sadio, um tanto cabeludo e com um choro extremamente vigoroso. Chamaram-lhe Paul. Paul "da floresta”. Paul, o que precisava 'pertencer'. Mãe e filho, acompanhados do pai, ainda permaneceram alguns dias de júbilo no hospital para se recuperarem dessa enorme batalha que foi nascer. Porém, talvez, e com grande pesar, esses tenham sido os únicos momentos felizes dessa nova família que já começava a se despedaçar por imposição do "Supremo Fascista”. O SF que Paul, a partir daquele instante, sempre iria combater, ironizar e blasfemar. E que nunca poderia vencer, apenas tentar de todas as formas reduzir sua maléfica pontuação. Ao chegarem em casa, ainda exibindo um belo e orgulhoso sorriso, descobriram que as duas filhas, as duas lindas crianças, as mais admiráveis e adoráveis meninas daquela decadente comunidade, haviam morrido de febre escarlatina.

Foi extremamente terrível. O Supremo Fascista já aviltava o ainda bebê Paul. Que nunca compreenderia seu destino. Que nunca aceitaria a realidade. Que nunca reverenciaria o desconhecido. A dor de Anna era irrefutável e inconcebível. Ela segurava, com sua mão esquerda, e bem próximo ao seu coração selvagem, a sua nova e agora única paixão e sentido. Já com a mão direita, num misto de desespero, loucura e devastação, tentava inutilmente trazer à vida as duas meninas que nem mais seriam capazes de sonhar. Aquela pavorosa descarga emocional percorreu, abalou e perturbou para sempre a vida de Paul. Anna, Lajos e Paul nunca conseguiram compreender essa imposição do destino. Nunca. Dizem que jamais ouviram-se gritos tão altos de agonia e destruição naquela pequena comunidade judaica em Budapeste. Dizem que aquela inarrável e inefável dor só ocorrera nos pogroms e na Shoah. E dizem também que naquele mesmo instante, ainda sem muito entender as razões e os insultos da vida, surgia o maior resolvedor de problemas matemáticos de toda história.

\section{2.}

Antes da Primeira Guerra Mundial, a vida dos judeus em Budapeste era até confortável, se comparada aos outros lugares da Europa. Havia sim discriminação, mas não era exagerada: “Os Habsburgs não eram realmente antissemitas. Isso significava 
na Hungria que eles não detestavam os judeus mais do que era apropriado". Os Habsburgs emanciparam os judeus em 1867 e a emigração judaica foi incentivada pelas novas leis do país. Queriam atrair esses mercadores, comerciantes, doutores e intelectuais para a Hungria. Porém, o objetivo subterrâneo que tinham era que essa comunidade se assimilasse, que aceitasse essa nova cultura e contribuísse para a criação de um novo estado econômica e intelectualmente forte. Assim, ofereciam títulos reais aos proeminentes judeus que aceitassem, e se adaptassem, ao novo e talvez próspero lar. Dentre eles, o famoso banqueiro Max Von Neumann, pai do que viria a ser um dos grandes e raros matemáticos, John Von Neumann, recebeu um título de nobreza em 1913, e o importante matemático, Andrew Vázsonyi, que na verdade era Endre Weiszfeld, também abraçou essa nova cultura.

Com a assimilação e a recepção dos judeus na Hungria, essas famílias acabaram tendo muito sucesso. Estima-se que a população judaica, que girava em torno de $5 \%$, possuía $37,5 \%$ de todas as terras, eram 51\% dos advogados, $60 \%$ dos médicos e $80 \%$ dos empresários. Um número que despertava a atenção, e também a inveja, de muitos ao redor. Mas essa situação não seria sustentada por muito tempo, obviamente. Com o assassinato do Arquiduque Franz Ferdinand pelo sérvio Gavrillo Princip, o Império Austro-Húngaro declarou guerra à Sérvia e à Rússia e a Primeira Guerra teve início. As coisas começavam a mudar em toda a sociedade e também na pequena família de Paul.

Lajos, pai de Paul, foi para o front lutar por uma causa que não era sua, e que não acreditava. Acabou tendo a sorte de ser capturado na fronteira com a Rússia, e enviado para Sibéria por longos e dolorosos seis anos. Uma amarga imposição que todos tiveram que acatar.

A infância de Paul foi muito triste e solitária. Ele sentia o fardo que carregava desde seu primeiro dia de vida. Seria ele o único que poderia trazer alegria, esperança e amor para a família despedaçada pela dor da morte das meninas. Era sua responsabilidade, seu destino, sua sorte, preencher de carinho e orgulho os corações dos pais que sempre estariam incompletos e faltantes. A Guerra, e também a morte, têm sempre muito mais vítimas e infortúnios do que contabilizam os insignificantes e abstratos números e estatísticas.

E Paul ainda era muito criança quando seu pai foi preso e 'desapareceu' do convívio com eles. Mais uma terrível dor com que ele teria que conviver dia a dia. $\mathrm{O}$ sofrimento do desconhecimento, da ignorância, da completa ausência de notícias e certezas em relação à saúde, à vida e ao paradeiro do pai era ainda mais um drama com que Paul e Anna teriam que conviver. E com ele, ou na prisão ou morto, viviam essa terceira e terrível margem do rio tendo que recalcar as mais secretas angústias da alma. Assim, para conseguir sustentar a família do pai ausente, a mãe muito se esforçou. Ela dava aulas de matemática numa escola afastada da cidade e se encon- 
trava muito raramente com o filho. Uma falta que Paul nunca foi capaz de suprir, obrigando-se a se alienar lentamente das funções e atividades reais.

Entretanto o trauma sempre vagou na vida dessa família. O temor de que o contato com as outras crianças do colégio pudesse adoentar o pobre e já frágil menino fez com que Paul passasse a receber uma educação particular com um tutor. A mãe revivia constantemente o pesadelo da perda de Klára e Magda, e não podia conceber o desaparecimento também do pequeno Paul. Assim, o garoto estudou sozinho até o Ensino Médio e, mesmo quando mais velho, durante alguns ataques de desespero e aflições de sua mãe, acabou se escondendo da vida, das pessoas, das coisas práticas de uma vida que precisava, mas não podia, ser vivida. Enclausurado em sua casa, e em sua falseada vida, vislumbrava uma outra e fantástica realidade.

E o menino, sozinho, sem amigos, e quase sem família, mas sentindo a necessidade de pertencer a alguma coisa incompreensível, acabou se apaixonando pela abstração, pela estética e pela indefinição dos números. Eles, esses pequenos e insignificantes algarismos, podiam aproximá-lo magicamente de sua faltosa mãe, já que ofereciam uma resposta exata do dia e da hora em que a reencontraria novamente. A matemática era a certeza do amor que Paul sempre buscava, e por isso nunca mais a abandonou. Ele, mentalmente, contabilizava quantas horas, quantos minutos e quantos segundos faltavam para que sua mãe voltasse do trabalho e o cobrisse de beijos, de abraços, de carícias. Também queria muito saber o tempo que faltava para as férias de verão. Esses eram os momentos mais felizes de sua vida. A exclusividade do amor materno. Assim, diante da contingência e do absurdo da vida, a matemática surgiu como uma possibilidade mínima de controle. De prazer. De certeza. E por ela ele se apaixonou perdidamente. Encantado pelos números, e por alguma segurança e exatidão que eles gratuitamente ofereciam, Paul passou a amar o cálculo desde muito, muito pequeno.

3.

E toda a História é cheia de guerras, brigas, desavenças, acasos e crimes bárbaros. Sem razão e compreensão fáceis. A Hungria, como já dizia Paul, sempre escolhia o lado do perdedor para se aliar. Assim, os Fascistas resolveram enfrentar os Comunistas e, claro, culparam os judeus por todos os problemas daquela época. Milhares de judeus foram mortos e torturados, e outros milhares tiveram que fugir de lá. Desses muitos judeus húngaros, os criadores futuros da bomba atômica, Edward Teller, John Von Neumann, Leo Szilard e Eugene Wigner, ironicamente acabaram se refugiando na Alemanha, mas tempos depois conseguiram fugir dos nazistas e partiram para os Estados Unidos. E essa memória coletiva das desgraças sempre assustou Paul, compelindo-o a se afastar cada vez mais do mundo tangível. 
Anna Erdös, mesmo diante das perseguições e das diversas ofensas direcionadas aos judeus, resolveu permanecer em Budapeste com seu filho. Possuíam amor e carinho pela cidade, mas podiam perceber diariamente, e não sem sofrimento, que fatalmente se tornariam alvos. Espancamentos, mortes e repressões se espalhavam pela Hungria, e encontravam nos judeus uma forma de expiar todo o descontentamento em que a população estava imersa. As famílias judias, supostamente convertidas e assimiladas, começavam finalmente a enxergar que não eram, e que nunca seriam vistos de outra forma, senão como "bastardos" e "malditos" judeus.

Lasjo e Anna nunca foram judeus praticantes, se é que existe essa definição. Eles, como tantos judeus, viviam entremeados por paradoxos, negações e dificuldades em relação ao 'ser' e ao se 'sentir' húngaros e judeus, além de eternamente estrangeiros e errantes. Talvez sejam esses os segredos e a pulsão criativa e vigorosa da cultura judaica, e tudo isso tenha sido introjetado por Paul. Segundo um outro matemático, László Babai, “quando o pai de Erdös estava cortejando sua mãe, ele a visitou uma vez no Yom Kippur, um dia santo de introspecção, e a encontrou em jejum e lendo Maupassant. Ele ressaltou o paradoxo sentido nessa combinação. Ela concordou. E, derramando lágrimas, Anna abandonou as antigas tradições.”. A tradição judaica sempre foi deixada de lado por muitos na falsa ilusão de uma assimilação e de uma possível aceitação pelo outro. Mas essa conjectura seria enfaticamente rejeitada nos fornos de Auschwitz, como vivenciaria a família de Paul.

Assim, não se importando com religião alguma, mas completamente inseridos nesse mundo inconsistente e cada vez mais insustentável, Anna sugere a Paul que eles se batizem buscando uma solução final para o problema da perseguição. Mais uma das inúteis tentativas judaicas para fugir do certeiro destino. Entretanto Paul, com seis anos de idade e já mostrando uma mente extremamente pragmática e matemática, não aceitou: "Bem, você pode fazer como quiser, mas eu vou permanecer da forma como nasci”. Mais tarde ele se recordará desse momento, como se recordará de todos os postulados e conjecturas que elaborou. E de todo sistema lógico e estrutural que seguiu, mesmo sem se apaixonar pelos enunciados, ou mesmo sem se preocupar com a semântica. Apenas buscando uma solução esteticamente bela para um dado problema. Ele se lembrará falaciosamente que "ser judeu não significava nada para mim. Nunca significou”, e que talvez toda essa cultura nunca tenha servido verdadeiramente para nada (mas irrefutavelmente para tudo).

E a vida é cheia de surpresas. Algumas felizmente boas. Surpreendentemente, após o desaparecimento total, e quase o esquecimento ou o recalque da memória da família perdida, Lasjo volta da guerra em 1920. Ele retorna, mas não sem as marcas indeléveis e inacessíveis da Guerra. Lasjo retorna e se espanta com o crescimento e também com a ausência sentimental do filho. Ele já tinha criado uma barreira 
para não sofrer mais, para não se desiludir, para não se decepcionar tanto. Outras e infinitas perdas incomensuráveis das malditas e estúpidas guerras. (Em seu âmago, Paul ficou plenamente feliz com o retorno de seu pai. Porém, por nunca conseguir demonstrar nenhum teorema acerca da contingência, do transitório e do imponderável, nunca manifestou tal alegria. Pelo contrário: ele sempre esperou que a vida sorrateiramente o privasse do amor e do cuidado de seu pai).

Nesse retorno, Lasjo se dá conta que a situação dos judeus em sua cidade havia se tornado insustentável. Nesse mesmo ano é outorgada a Numerus Clausus, uma legislação inteiramente antissemita. A partir daquele momento, todos os privilégios semitas haviam sido suspensos e finalmente constatou-se que os judeus não eram e nunca seriam bem-vindos. Em parte alguma. Em tempo algum. Além disso, pela nova lei, apenas $6 \%$ dos judeus poderiam entrar nas Universidades, o que comprometeria o futuro do precoce e brilhante Paul. Ele, que já demonstrava genialidade, poderia ter se tornado mais um dos muitos fracassados. Mais um dos numerosos insignificantes e esquecidos pela História. Mais um dos exterminados sem razão nenhuma. Porém, mesmo assim, a família ainda se manteve na Hungria. Teimosos, obstinados, inconsequentes. Como muitos. E com bastante medo, pânico e insegurança. Eles ainda acreditavam em alguma coisa, em alguma salvação, em alguma possibilidade de continuarem vivos. A fé definitivamente não é algo mensurável e compreensível.

4.

Mas os grandes cérebros ainda conseguiam entrar nas universidades. Apesar das cotas ínfimas destinadas aos judeus, os ganhadores das olímpiadas nacionais de ciências tinham acesso direto à Universidade. Uma mísera esperança para Paul nessa Waste Land. Infelizmente, outras maravilhosas mentes foram privadas de lapidação acadêmica e desapareceram completamente. Uma falta eterna e imponderável da incoerência humana. Quem sabe do que seriam capazes esses 'segundos' lugares 'olímpicos'? Quem sabe do que seriam capazes as mentes e as almas extintas pelas estúpidas perseguições, genocídios, e pela Shoah? Quem sabe como seria esse 'outro' mundo? Muito melhor, se consideramos esse atual o pior dos mundos, ou já inteiramente destruído, considerando esse mundo de agora como o melhor dos mundos possíveis.

Pelo seu brilhantismo, ineditismo e quase perfeição, Paul nunca teve problemas em ser o primeiro da classe e dos torneios. Ele já se alienava sentimentalmente do mundo. A sua alegria estava inteiramente na matemática. E por isso nunca sentiu qualquer tipo de pressão em ambiente algum. Era ele, ele mesmo, e mais ninguém, dançando e saboreando os prazeres e as delícias dos números, e de suas invenções e descobertas. Assim, aos dezessete anos, ingressou na Universidade Pázmány Péter 
em Budapeste. Quatro anos depois, ele sairia de lá com seu doutorado e com uma infinidade de amores (problemas matemáticos) para resolver e para se alienar ainda mais do terrível mundo em que estava inserido.

Ele só queria viver as suas centelhas de amor. O amor incomensurável, eterno e invariável de sua mãe. Sublime Amor. E também o amor que ele inventou através da matemática. Da mãe das únicas certezas, belezas e crenças que concebeu. Assim ele era devoto do Amor. Do amor matemático. E de tudo, que de alguma forma podia e devia ser matematizado e resolvido. Ele ainda vivia no mundo utópico conjecturado por Hilbert, onde jamais existiriam os terríveis ingnorabimus. Ilusões, perdições e devaneios hoje completamente esquecidos. Entretanto, Paul precisava conhecer tudo, de todas as maneiras, de todas as formas, estruturas e sensações. A matemática precisava substituir a contingência e a irrelevância da Vida. Assim ludibriava Paul. Assim sonhavam e falseavam os muitos matemágicos espalhados pelo mundo.

E Paul ia se tornando um sujeito muito divertido, leve e alheio, já que tudo se transformava em matemática. Tudo era apenas uma simbologia ou uma linguagem para descobrir os segredos do seu maldito e maior inimigo: o Supremo Fascista. Combatendo esse seu Deus, ele desvelaria finalmente o amor que tanto buscava. Assim ele criou sua própria forma de interagir. Chamava "criança” de "épsilon", "netos" de "épsilons ao quadrado", "álcool” de "veneno", "música” de "barulho”, "mulheres” de "chefes", “Joe” para "USSR”, "Sam” para "USA”. Não sabia mais interagir 'normalmente' com as pessoas, e com o mundo, apenas imaginava uma forma de desvelar a beleza escondida pelas diversas equações e inúmeros problemas. E assim foi capaz de encontrar descuidadamente a sua felicidade.

Para Paul havia uma frase que resumia a dor e a história de seu 'também' povo: "Temetni tudunk: Como enterrar pessoas - isto é definitivamente uma coisa que sabemos ". Nascido com a incrível responsabilidade de tentar abrandar esse gigantesco vale de lágrimas que derramava e despedaçava sua família, Paul enfrentava diariamente o Supremo Fascista responsável único por todas as contingências e belezas da vida. "Quero mostrar que Deus é mau. Não quero dizer que isso é correto ou que Deus de fato existe, isso é apenas uma piada. Quando me perguntam: 'Qual o sentido da vida?' respondo: 'Demonstrar, conjecturar e encontrar belezas, mas sempre deixar a pontuação de SF baixa'. O jogo com SF é o seguinte: se você faz algo ruim, SF marca dois pontos. Se você não faz uma coisa boa, sendo que poderia ter feito, SF faz pelo menos um ponto. E se você faz algo realmente bom, então nem você nem o SF pontuam. O objetivo da vida é deixar o SF com a pontuação mais baixa possível”. Obviamente, ele nunca conseguiu suprir essas necessidades, apesar dos mais de mil e quinhentos problemas complicados e relevantes que resolveu. Ele acreditava ingenuamente que "a matemática fosse a chave para alcançar a verdade transcendente. Resolver um problema seria um triunfo sobre o desconhecido". 
Paul jamais logrou manter a pontuação de SF baixa (exceto em seu último suspiro). "Maldito Fascista”, sempre praguejava.

5.

Em 1934, Paul decide finalmente abandonar a Hungria, esse "país semi-fascista”. Ele vai para a Inglaterra realizar seu pós-doutorado. E, a partir desse momento, sua vida de judeu errante tem início. O verdadeiro e único Ahasverus da matemática. Ele mal dorme na mesma cama por duas noites seguidas. Ele viaja para colaborar com outros matemáticos em Cambridge, Londres, Bristol e todas as universidades pelas redondezas. Ele parte para sua jornada rumo ao desconhecido, em busca de problemas e amizades matemáticas que atravessam fronteiras, e que não se preocupam com credo, cor, religião. Ele está em busca constante, e quase sufocante, pelo amor. $\mathrm{O}$ amor pela matemática que desvelaria os números secretos desse capcioso e maligno Deus.

Secretamente (até hoje ninguém nunca soube disso), Paul sonhava em ir à Alemanha conhecer e encontrar os muitos matemáticos que tanto admirava. Lá viviam fabulosas e encantadoras mentes com quem ele poderia compartilhar problemas, soluções e maravilhas. Lá habitava essa incrível e milenar cultura, essa saborosa língua, e essa quimérica racionalidade humana. A mãe contemporânea de toda sabedoria... Mas o Supremo Fascista já tinha criado a sua mais célebre, contingente e gloriosa criação: Hitler. E Paul, apesar do desejo e admiração profundos por essa cultura, nunca pôde se relacionar com os muitos matemáticos que lá viviam. Paul faria da sua vida uma homenagem a esses matemáticos alemães que pereceram inutilmente pelas mãos da total incoerência humana.

Porém, mesmo assim, Paul desfrutou seus tempos ingleses. No seu segundo dia em Cambridge, conheceu G. H. Hardy, um apologista da matemática e também um blasfemador contra Deus. As almas atormentadas e maravilhadas dos dois se reconheceram. Hardy chamava o seu Deus de "meu inimigo pessoal", mas de alguma forma, assim como Paul, acreditava na beleza suprema e universal dessa linguagem matemática inventada exclusivamente por Ele. Em seu obituário publicado na Oxford Magazine, Hardy teria tido "uma profunda convicção de que a verdade matemática descreve um universo brilhante e claro, requintado e bonito em sua estrutura, em comparação com o mundo físico, turvo e confuso. Foi isso que fez seus amigos pensarem em sua atitude em relação à matemática como sendo algo essencialmente espiritual, bem próximo de uma religião”. Essa também se tornaria a nova religião de Paul.

Hardy muito se parecia com o jovem Paul nas suas excentricidades e genialidades. Mas, diferente do matemático húngaro, nunca teve a obrigação de mostrar a todos que era o melhor. Hardy jamais gostou de ser o centro das atenções. Gênio 
precoce, errava propositalmente algumas questões, pois não queria se graduar como o número um da turma e ter que se expor publicamente. Ele se incomodava bastante com a sua autoimagem (ou será que já temia o terrível problema matemático da autorreferência?), e em todos os hotéis em que se hospedava cobria os espelhos para nunca ter que encarar a sua própria imagem refletida. Porém, era considerado por muitos um sujeito esteticamente bonito. Russell gostava dos seus "olhos brilhantes", Littlewood o considerava "bonito", James Newman dizia que ele era "extremamente bonito e gracioso". Hardy ainda tinha outras paixões. Era fascinado por esportes, sobretudo cricket e tênis, diferente de Paul que era o mais celibatário, casto e devoto matemático que toda a História já idealizou.

A questão sexual era um enigma tanto para Hardy quanto para Paul. Talvez um problema não matematizável, e por isso extremamente pavoroso e amedrontador. Paul disse uma vez: "Na verdade, eu tenho uma anormalidade. Eu não suporto o prazer sexual. É uma anomalia curiosa. É quase única”. Seria essa anormalidade fruto do medo diante do inconcebível? Daquilo que não era e nunca poderia ser mensurável? Ou será que ele nunca se permitiria sentir um outro prazer que não fosse através da matemática per si? Já Hardy, por sua vez, foi membro de um grupo de discussão conhecido como 'Os Apóstolos', onde o homossexualismo, considerado por eles como o "Grande Sodomita", era visto como a mais espiritualizada forma de amor. Não era obrigatório ser homossexual para se tornar membro do grupo, mas era o padrão dominante, pois "mesmo os mulherengos fingiam ser sodomitas, senão não seriam considerados respeitáveis". Segundo Littlewood, Hardy era um “ homossexual não-praticante”. Assim os dois amigos sofriam e recalcavam a sua sexualidade, e tudo aquilo que não era produto da beleza matemática.

Hardy, assim como Paul, gostava de trabalhos em parcerias. Considerava essas trocas como resultado e recompensa do amor que partilhavam. Ele teve dois célebres coautores: Littlewood e Ramanujan. Com Littlewood trabalhou por trinta e cinco anos, e publicou cerca de cem artigos. Com Ramanujan esteve junto apenas por quatro anos, mas publicou artigos maravilhosos. E para Hardy, Ramanujan foi o verdadeiro matemático que nem ele, nem ninguém mais conseguiu ser. Paul uma vez perguntou a Hardy qual teria sido sua maior descoberta. "A descoberta de Ramanujan” respondeu, sem vacilo algum, o grande apologista.

Para Hardy e Paul, a demonstração matemática era a beleza mais suprema. Mesmo a prova de sua própria morte valeria a pena. Uma vez Hardy disse sobre Russell: "Se pudesse encontrar uma prova de que eu iria morrer em cinco minutos ele, evidentemente, sentiria certo pesar em me perder, mas essa tristeza seria superada pelo prazer na prova. Eu estaria de acordo com ele e não ficaria de todo ofendido". Segundo Paul, Hardy dava notas aos matemáticos. Littlewood receberia um 30. Hardy, ele próprio, um 25. Hilbert um 80. E Ramanujan um 100, mesmo sem ser 
capaz de demonstrar muitas de suas 'visões'. Paul sempre buscou essa beleza, que para ele também era a busca inalcançável pelo Amor.

Ao fim de sua vida, Hardy virou um sujeito decadente e desiludido. Segundo ele, um matemático que escreve sobre Ciência, ao invés de fazer estritamente matemática, está completamente acabado. Assim foram as suas lamúrias em seu famoso A Mathematician's Apology: "É uma experiência melancólica para um matemático profissional acabar escrevendo sobre os matemáticos. A função de um matemático é fazer algo, provar novos teoremas, fazer progressos na matemática, e não escrever sobre o que ele ou outro matemático fez". Hardy acreditava, até a chegada do profeta Paul, que só se poderia descobrir novos e surpreendentes resultados na matemática durante a juventude. Porém Paul, aos oitenta e três anos, refutava diariamente essa conjectura de Hardy, ainda resolvendo problemas relevantes. Talvez Hardy nunca tivesse escrito sua "Apologia” (ou alteraria muitas partes) se houvesse convivido por outras décadas com o fantástico Paul.

6.

Nessa busca desenfreada pelo amor, Paul descobriu os 'primos' e passou a considerá-los a mais bela das criações divinas. Também estimava esses famigerados 'primos' como a mais enigmática e complexa descoberta humana. Sim, Paul era platônico, devoto e apaixonado. Segundo o amigo e matemático Vázsonyi: "Erdös vivia no mundo dos números primos. Eles eram seu mundo. Ele tinha uma afinidade especial por eles. Quando tinha vinte anos, anunciou iria provar o grande Teorema dos Números Primos por meio de cálculos elementares e usando o antigo crivo de Erastóstenes. E vinte anos mais tarde, ele faria isso. Os números primos estiveram em sua mente por toda a sua vida."

Assim, o amor pelos primos o fez se aproximar dos trabalhos do fabuloso fabulista Ramanujan. Este iletrado aprendera matemática através do livro Synopsis of Elementary Results in Pure Mathematics, porém não possuía nenhum rigor matemático. Ele se encantara com os números e, através de seus insights e de seus sonhos, logrou encontrar maravilhosos resultados na Teoria dos Números. Mas somente ele e sua 'deusa' podiam fazer uso de uma linguagem própria, um tanto adulterada e diferente da comunidade científica matemática. Hoje ele não teria sido aceito por ninguém, mas felizmente isso nunca afugentou Hardy, que ousou trazê-lo a Cambridge e, sob seus cuidados e carinhos, o transformou na sua maior criação, alegria e tristeza. Paul sempre desejou se igualar ao brilhantismo e à pureza de Ramanujan. Entretanto, ainda queria mais. Mais perfeição. Mais luz e brilhantismo. Paul perscrutou incansavelmente pela beleza da prova perfeita. Pela descoberta da verdadeira e única essência de Deus. 
Um problema que Paul havia sonhado em resolver apresentando uma prova limpa e de extrema harmonia - Prime Number Theory -, já tinha sido 'melhorado' e 'embelezado' por Ramanujan em 1913. O mundo metafísico, segundo as crenças de Ramanujan, lhe enviava as fabulosas respostas do livro sagrado matemático - The Book. Ramanujan era sacerdote e temente à Deusa Namagiri: "uma equação para mim não tem nenhum significado, a menos que expresse um pensamento de Deus" que através de seus anjos e demônios o conduzia a fim de desvelar a Harmonia matemática.

Paul, diferente de Ramanujan, nunca foi capaz de sonhar. Tampouco foi capaz de se comunicar com o Além e escrever seus ilusórios insights. Ele, quase como uma máquina pragmática, queria apenas demonstrar tudo da maneira mais sagrada e bela possível. Queria, e muito, enfrentar seu malicioso e perverso inimigo.

Paul sempre falava do tão sonhado e almejado Book. O livro onde todas as belas e maravilhosas demonstrações estavam escritas. A única, e mais bela e sublime forma de Arte. A suprema Deidade. Segundo Paul, sempre existiria a mais perfeita 'prova'. The Book Prove. Para ele os verdadeiros matemáticos deviam buscar exaustivamente essas demonstrações, almejando revelar os mistérios escondidos dessas transfinitas e inconcebíveis páginas da Criação.

\section{7.}

Paul, mesmo se dedicando inteiramente à matemática, sentia falta de seu país. Uma outra forma de amor, carinho e apreço. Vivia em Cambridge, mas fazia de tudo para visitar a sua querida mãe, e também seus amados colaboradores, em sua cidade natal. Infelizmente, a partir de 1938, a situação política complicou-se ainda mais. Uma destruição jamais concebida estava próxima a irromper.

Em setembro desse mesmo ano, Paul partiu para Princeton para realizar um fellowship no Instituto de Estudos Avançados. Apesar de ter gostado muito, e de ter vivido um período extremamente prolífico, ele permaneceu nessa universidade somente um ano e meio, já que os scholars o julgaram "grosseiro" e "não-convencional" demais. Ele mostrava uma certa inaptidão social, mas possuía um grande brilhantismo e ineditismo jamais vistos. Porém, os supostos acadêmicos de Princeton só se prenderam ao lado pessoal do matemático e não renovaram seu contrato. O mundo acadêmico com suas muitas mazelas, incertezas, medos, desconfianças e inúmeras asneiras.

Porém, para a sorte de Paul, e de todos nós, um amigo e também colaborador, Stanislaw Ulam, ao saber da rejeição de Princeton, convidou Paul para se juntar a ele em Madison, Wisconsin, onde era professor. Paul nunca se importou com a desaprovação de Princeton. Ele não se preocupava com dinheiro, status, prestígio. Só 
queria fazer matemática onde quer que fosse. E conseguir seu quinhão de felicidade que essa ciência poderia lhe trazer.

Mesmo com a matemática preenchendo sua alma, Paul viveu extremamente triste nesse período: ele não recebia nenhuma notícia da sua querida mãe, pois a troca de cartas entre os Estados Unidos e a Hungria estava interrompida em função da Guerra. Uma grande desgraça que exterminou uma cultura inteira, e fez com que Paul se dedicasse ainda mais às 'certezas' matemáticas.

A parceria entre os Ulam e Paul foi muito produtiva. E poderia ainda ter se transformado em algo bem maior. Em 1943, Ulam deixou a Universidade e foi para Los Alamos participar do projeto da construção da bomba atômica. Convidou Paul para se juntar aos esforços 'aliados'. Sugeriu que ele escrevesse para Edward Teller oferecendo seus importantes e fundamentais 'serviços'. Porém, Paul foi considerado 'desqualificado', já que na sua carta de apresentação mencionou que voltaria a Budapeste assim que a Guerra acabasse. Ele tinha que reencontrar, a qualquer custo, a mãe. Paul também não aceitou assinar um documento dizendo que nunca poderia falar sobre os trabalhos realizados em Los Alamos. Ele queria, e precisava, divulgar seus resultados. Demonstrar e revelar os segredos do terrível SF. Enfrentar e minimizar a pontuação do Inimigo. Ele não assentiria jamais em permanecer em silêncio. Assim, seu destino foi outro. E também o da catastrófica bomba atômica.

Em 1943, Paul partiu para Purdue, e se alienou ainda mais do mundo. Ele passou a não ter horários, não diferenciava mais o dia da noite, e vagava constantemente pela região apenas 'pensando'. Uma vez foi parado por um policial à meia-noite. Não tinha documento nenhum. Ao ser questionado pelo seu comportamento 'suspeito', Paul respondeu que estava apenas “demonstrando alguns problemas matemáticos”. Trivial.

Em 1944, a situação na Hungria começou a piorar extremamente, sobretudo para os judeus. No dia 7 de julho, mais de 437.000 judeus foram deportados para Auschwitz. A mãe de Paul, junto com outros 20.000 judeus, foi obrigada a permanecer confinada no Gueto de Budapeste. A morte rondava a região. Os Campos de Extermínio já eram realidade e assombravam a racionalidade humana. Mas em 14 de fevereiro de 1945 as tropas soviéticas libertaram a cidade. Alegria, exaltação e completa destruição. Nunca mais seria permitido ao mundo escrever poesia. Nunca mais. E em agosto de 1945, Paul recebeu finalmente um telegrama da mãe. Ela e a prima Magda Fredro estavam vivas, mas os quatro tios haviam sido assassinados nos Campos de Extermínio e o pai de Paul havia falecido em 1942 de ataque cardíaco. Logo após receber esse telegrama, Paul resolveu mais um de seus problemas matemáticos. Era sua forma analítica de exorcizar o monstruoso sofrimento que o apunhalava. 
8.

Se existia um problema, haveria uma solução. Isso era válido tanto para a matemática, acreditavam Paul e Hilbert (este ainda mais ingênuo que o primeiro), quanto para as relações humanas. Não poderiam estar mais enganados.

Mesmo assim, Paul estava convencido de que através da matemática poderia ajudar os amigos e melhorar o mundo. Ele prezava muito seus colaboradores-irmãos e, ao falar somente das matemáticas, ao discutir problemas, ao conjecturar e ao especular mundos, dimensões e funções possíveis, Paul estaria, imaginava, compartilhando seu amor, sua amizade, seu companheirismo. Dessa forma estaria se aproximando do Sublime. Através dos problemas e das equações, Paul se via mais próximo de uma certa santidade e Utopia. Tanto foi assim que ele muito ajudou alguns companheiros, em momentos complexos e conturbados. (A verdade é que socorrendo seus amigos ele buscava sua própria salvação).

Ulam, por exemplo, ao retornar de Los Alamos, foi internado às pressas com uma terrível enxaqueca, uma dormência no peito e uma imensa dificuldade para articular a fala. Uma inflamação tomava conta de seu cérebro, talvez em virtude da radiação com que por tempos conviveu. Um buraco foi feito em seu crânio para aliviar a pressão e ele ficou em coma por alguns dias. (Durante esse período, Paul aperfeiçoou algumas demonstrações que tinham feito em parceria. Era sua forma de homenageá-lo. Era sua oração, sua súplica, sua prece para que o SF não levasse seu grande amigo). Logo após acordar, ainda atordoado, o médico lhe fez algumas perguntas simples. Ele as julgou extremamente ridículas. Felizmente não havia se comprometido a sua inteligência. Mas ele estava inseguro e com medo de ter esquecido a beleza e as certezas matemáticas.

E foi aí que o amigo apareceu para ajudá-lo. Algumas semanas depois do coma, Ulam já estava mais forte e pôde finalmente retornar para sua casa. E Paul, excitado e extremamente feliz ao se dar conta das promissoras notícias do amigo, dirigiu-se ao hospital para buscá-lo. E já no carro começou a desafiar Ulam a resolver diversos problemas matemáticos. E propôs muitos outros para trabalharem juntos. E explicou algumas simplificações que fez em diversos artigos que publicaram. Ulam, ainda zonzo e perturbado, foi lentamente relembrando esses teoremas e recobrando sua confiança e sua vontade de viver. Paul se hospedou em sua casa e não lhe deu, por um segundo sequer, descanso. Costumava se levantar às quatro da manhã, dirigirse ao quarto do amigo e pronunciar suas memoráveis palavras: "My brain is open”. Ulam faleceu apenas quarenta anos depois, tendo trabalhado com matemática de alto nível até quase seu fim. Paul escreveu em seu obituário: "Ele estava realmente feliz por ter conseguido evitar os maiores males, velhice e estupidez, já que morreu subitamente de parada cardíaca, sem medo ou dor, enquanto ainda estava apto a provar e conjecturar". Paul, com sua matemática, realmente fez a diferença. 
Outro amigo que Paul ajudou foi o matemático Jon Folkman, que trabalhava na Rand. Ao ser diagnosticado com um tumor no cérebro, teve que realizar uma difícil cirurgia. Logo após despertar da cautelosa intervenção médica, Paul já estava esperando o amigo com perguntas e problemas matemáticos. Paul sofria, mas a única forma que encontrava para tratar a dor e a preocupação com o amigo era convidando-o a resolver mais e mais problemas. A escrever outros artigos. A resolver e criar outras conjecturas. A colaboração era a única forma de amor que conhecia. E que tanto venerou. Infelizmente, Folkman nunca conseguiu superar essa terrível doença e resolveu escolher o dia do seu fim, aos trinta e um anos de idade, com um tiro certeiro na cabeça.

Paul queria e precisava ajudar. Todos. Mas só através da matemática. Talvez ele tenha mudado o destino de todo saber humano. Foram muitas contribuições. Paul conheceu, e auxiliou, o mais enigmático e complexo matemático de todos os tempos, que além de trabalhar com a ontologia e a metafísica Deus, provou a incapacidade de um sistema aritmético demonstrar tudo: os famosos Teoremas da Incompletude. Colegas no Instituto de Estudos Avançados de Princeton, Gödel também teve seu bloqueio, seus temores e suas inseguranças, e Paul sempre esteve a seu lado, mesmo não concordando com as pesquisas que conduzia: "Ele era certamente um intelectual importante. Entendia de tudo, mesmo dos assuntos que não trabalhava. É estranho o quão pouco ele publicou. Ele certamente poderia ter feito mais coisas. Eu sempre discutia com ele, já que seus interesses se desviaram para as questões metafísicas”. Alguns perturbadores artigos de Gödel só foram publicados pelo incentivo de Paul. E esses artigos ainda assombram aqueles que se preocupam com os primórdios do pensamento.

\section{9.}

Paul conheceu praticamente todos os grandes cientistas de sua época. E nunca se vangloriou. Ele só se interessava pela matemática mais pura e mais bela que a mente humana poderia desvendar. Ao conhecer Einstein, por exemplo, não julgou as conversas proveitosas: "Eu não era amigo próximo de Einstein, mas eu expliquei-lhe o Teorema dos Números Primos. Claro que ele entendeu e disse que era bom, mas tinha pouco interesse nos detalhes". Como não ter interesse pelos apaixonantes números primos? Como não se espantar com a beleza dessas maravilhosas 'criaturas' divinas? Como não se petrificar diante da dificuldade e do supremo poder dessas pequenas deidades? Não, ele não poderia ser amigo, ou colaborador, de alguém que não vislumbrasse a essência do Criador. E mais: como perder tempo com política - coisa extremamente ridícula - que não impediria a contingência e a maldade da vida? "Temos que dividir nosso tempo entre fazer política e resolver equações. Mas, 
para mim, resolver equações é muito mais importante, e fazer política é apenas uma questão momentânea. Uma equação matemática permanece para sempre”. Einstein vivia num mundo que não era Sagrado e Eterno, segundo Paul, e por isso não tiveram nenhum laço de amizade.

Mas mesmo diante de toda devoção pelo seu trabalho, Paul percebia as dificuldades em relação ao novo mundo que se formava após a II Guerra. Ele, mesmo entregue inteiramente às soluções matemáticas, amava incontrolavelmente sua mãe. E sempre fazia tudo para visitá-la. Porém, as relações diplomáticas entre os países estavam se tornando cada vez mais estúpidas e complexas. Em uma de suas entradas nos EUA ele acabou perdendo seu visto. Passou efetivamente a não ter mais lugar no mundo. Era um cidadão húngaro, mas esse seu país não era definitivamente um bom lugar para se viver. E nem para ter um passaporte. Sem lar, sem vínculo e sem documentos, ele se viu obrigado a sair pelo mundo procurando alguém que o aceitasse. E aceitasse sobretudo sua matemática. Seus colaboradores ao redor do mundo se sensibilizaram. Queriam e precisavam ajudá-lo. A Holanda, a pedido de um amigo, concedeu-lhe um visto temporário que infelizmente não resolveu seus problemas práticos. Israel o aceitou como residente, mas ele não queria nada isso. Ele teimava em dizer que era húngaro, mas também um cidadão do mundo. A matemática não clamava por ser universal e divina? Por que ele também não poderia ser? Foi um período complicado para Paul. Porém, ele conseguiu sobreviver. Procurou mais e mais colaboradores pelo mundo afora, viajando com apenas duas malas e sem dinheiro, mas com a vontade de resolver cada vez mais problemas matemáticos. Era sua única forma de se abstrair da irracionalidade burocrática e de toda estupidez humana.

10.

Nesse período, alienado e sem lar, Paul produziu bastante. Entretanto, sentia muita falta de alguns colaboradores e, principalmente, de sua querida mãe. E finalmente em 1959, Paul conseguiu ser aceito novamente nos EUA. Foi uma enorme alegria. Ele poderia reencontrar alguns amigos e conhecer novas e brilhantes mentes.

Paul sempre teve um desejo íntimo por gênios precoces. Talvez uma forma de se reconciliar consigo mesmo e reviver seu passado traumático. Talvez uma forma de pulsão. Talvez a vontade pelo gozo. O gozo sexual que nunca lhe foi permitido. E quando voltou aos EUA seus colegas lhe apresentaram um jovem e surpreendente matemático. Eles se conheceram. Paul queria se sentir jovem e vivo novamente. Ele queria voltar a sentir o tesão pela descoberta do novo, do inédito e do espetacular que só os jovens seriam capazes de oferecer. E os dois se encontraram num café e Paul, compartilhando seu amor, formulou a seguinte questão: "Prove que, se você tem $n+1$ inteiros inferiores ou iguais a $2 n$, então haverá sempre dois deles que são 
primos relativos ". Paul admitiu que levara dez minutos para chegar a uma prova simples para essa formulação. Mas Louis Pósa, então com doze anos, mal havia terminado de tomar sua sopa e já provava o fascinante teorema. Genial! Pósa, segundo o próprio Paul, lembrava o brilhantismo e a perspicácia do precoce e também extraordinário Gauss.

Eles se tornaram amigos e amantes das funções matemáticas. E com apenas quatorze anos, Pósa escreveu o primeiro dos muitos artigos com Paul. Seu trabalho mais famoso e importante viria a ser publicado com quinze anos de idade, em Teoria dos Grafos. Pósa era uma promessa. O sonho de grandes soluções. A certeza da genialidade humana... Entretanto, ele nunca se sentiu preenchido e completo com o seu trabalho e com seu dom. Ele precisava de mais. De muito mais. De algo que julgou ser mais humano, mais prazeroso, mais carnal. Aos dezesseis anos, Pósa já dava sinais de possuir outras paixões e sonhos: "Eu preferiria ser Dostoievsky a ser Einstein".

Então, aos vinte anos, Pósa entrou para a turma do Bartleby e se calou. Doravante, passou a caminhar junto aos matemáticos precoces e aos endiabrados e taciturnos escritores Walser, Rimbaud, Juan Rulfo, Musil, Salinger, Valéry, Nassar, que silenciaram misteriosamente em momentos cruciais de suas vidas literárias e acadêmicas. Não produziu mais nada relevante para a dor e a tristeza de Paul.

Porém, o real motivo que libertou o jovem das suas aflições e angústias matemáticas foi ter conhecido os encantos de outro Deus. Talvez a mais sublime e perfeita criação Divina. Talvez a única obra que mente alguma poderá jamais entender. Apenas se encantar, glorificar e admirar diariamente. O jovem Pósa se apaixonou perdidamente pelas certezas indemonstráveis das virtudes, harmonias e simetrias das mulheres, coisa em que seu mestre Paul nunca poderia ajudá-lo. Pósa viveu inteiramente feliz quando esteve do lado de seus amores, mas passou parte da vida completamente devastado ao se desencontrar e ser rejeitado muitas vezes por elas.

\section{1.}

E a vida estava acontecendo, os teoremas estavam sendo demonstrados, mas o tempo passava. E a morte começava a assombrar mais uma vez a vida de Paul. Em 1964, Anna teve que começar a viajar com o filho. Por amor, por necessidade e por estar cada vez mais debilitada em função dos seus oitenta e quatro anos. Assim, ao longo dos próximos sete anos, Anna participaria de todas as palestras, conferências e colaborações em que Paul estivesse presente (exceto nas viagens à Índia. Tinham muito medo da comida e do clima de lá). Segundo Fedro, prima de Paul e única sobrevivente de Auschwitz: "Ele (Paul) era seu (Anna) Deus, seu tudo". Anna, mesmo sem entender o mundo em que Paul estava inteiramente imerso, preocupava-se enormemente com o querido filho. (A verdade é que ela 
ainda tinha pesadelos com a morte precoce de suas filhas. Acordava aos prantos durante as noites. Para acalmá-la, Paul lhe contava alguns de seus novos resultados e conjecturas. Ela não entendia muito bem, mas adormecia com as carinhosas palavras de seu amado filho).

Anna muito se preocupou com a vida sentimental do filho, e sempre sofreu com isso. Ela já era obrigada a dividir o filho com a matemática, e não gostava muito. Queria exclusividade nesse amor. Mas ela sonhava também que o filho pudesse encontrar alguém para lhe dar netos. E tinha muito medo de perdê-lo. Porém Paul nunca teve sequer uma namorada... ou namorado. Todo o amor de que necessitava sempre foi suprido pela mãe, e pelas equações e parcerias. Ele, acreditava, só poderia sentir o prazer matemático, e nunca o gozo pelo encontro dos corpos: "O privilégio do prazer em lidar com as mulheres não me foi dado. (...) Quando o sangue começava a fluir em meu pênis, isso me causava grande dor ". Paul viveu a alegria e o sofrimento dessa busca quase sufocante do encontro das almas... mas nunca pôde perscrutar o encontro dos corpos. Essa foi sua sina. Essa foi sua maldição. E essa foi sua mais profunda devoção.

E ele se convencia de sua 'monstruosidade': "É uma situação muito complicada. Basicamente, eu tenho uma anomalia psicológica. Eu não suporto o prazer sexual. É peculiar. Você sabe, eu tenho uma personalidade básica, mas sempre quis ser diferente das outras. É muito, muito enraizada. Desde muito cedo eu resisti automaticamente a pressão de ser como os outros.” Por que ele nunca procurou tratamento? Por que ele nunca pôde sentir o prazer humano? Por que ele teve que se tornar um asceta? Talvez Paul tenha sido um pactário. E talvez tenha sido por isso, e somente por isso, que SF tenha lhe revelado algumas das provas do grande e fabuloso Book.

12.

Em 1971, Anna morreu. Estavam numa conferência no Canadá e ela teve um sangramento de uma úlcera e, aparentemente, não foi atendida corretamente. Foi então que o mundo de Paul desabou. Uma dor jamais experienciada. Ele não tinha como continuar. Ele não tinha mais chão, e nem mais sentido para viver. Ele já não queria mais sentir qualquer tipo de prazer.

E foi aí que seus colaboradores o ajudaram. Eles apareceram com novos problemas e conjecturas. E os olhos de Paul brilharam novamente. Encanto. Fascínio. Arrebatamento. Ele conseguiu continuar. Ele voltou a enfrentar SF. Ele provou que nunca estaria acabado.

Ele começou a tomar antidepressivos e anfetaminas o tempo todo. E a trabalhar cada vez mais. Agora ele poderia se dedicar integralmente aos problemas ma- 
temáticos. O único amor que lhe restava. E foi nesse dia que a matemática venceu. Mais e mais problemas começaram a ser desvelados. "A nossa matemática é uma potente fortaleza" escreveu Paul Turán sobre as descobertas de Paul após a morte de sua mãe. Paul passaria a dormir muito pouco, a comer quase nada, a não conversar banalidades. Ele não mais poderia perder tempo com outras coisas que não fossem matemática.

13.

Paul foi o Forrest Gump da matemática. Por ser capaz de trabalhar em várias áreas da matemática, coisa quase impossível até para os deuses, ele acabou participando ativamente dos mais importantes e maravilhosos momentos da História da Matemática. Ele era próximo a Andrew Wiles quando o matemático, após anos de clausura, publicou a demonstração de um dos maiores problemas de todos: O Teorema de Fermat. Paul não concordou com seu método de trabalhar sozinho, encarcerado e solitário por longos oito anos. Ele apenas admirava o colega por nunca ter usado métodos computacionais. Algo que Paul nunca admitiu, já que "adulterava a beleza das demonstrações”.

Ele também esteve presente, e não gostou de forma alguma, quando Paul Cohen finalmente encontrou um exemplo comprovando a validade dos Teoremas da Incompletude de Gödel. Cohen demonstrou que a Hipótese do Contínuo era de fato indecidível, o que Paul nunca aceitou: "Se eu estivesse vivo daqui a mil anos, perguntaria: descobriram uma solução para a Hipótese do Contínuo ?”

Teria acabado a idealização da beleza nesse fatídico momento? Paul, recusando tal constatação, desdenhava: "O que você diria a Jesus se o visse na rua? Perguntaria se o Hipótese do Contínuo é verdadeira. E haveria três respostas possíveis para Jesus. Ele poderia dizer: Gödel e Cohen já ensinou-lhes tudo o que poderia ser conhecido sobre ele ; ou 'Sim, há uma resposta, mas, infelizmente, seu cérebro não está suficientemente desenvolvido para entender a resposta'; ou 'O Pai, o Espírito Santo, e eu estivemos pensando muito sobre isso antes mesmo da Criação, mas nós ainda não chegamos a uma conclusão “. Porém, a maioria dos lógicos aceitariam a primeira resposta”. Mas os teoremas eram corretos sim. SF era muito mais irônico e ardiloso do que Paul poderia conceber.

14.

Então, talvez, a grande genialidade de Paul tenha sido a de escolher exatamente os problemas que enfrentar. "Problemas que vale a pena atacar, provas por que vale a pena lutar". E por isso foi capaz de combater o seu grande inimigo.

Todos os artigos de Paul não foram sem razão. De forma alguma. Ele buscava as demonstrações e as belezas mais sagradas. As verdades mais escondidas. As ano- 
tações mais secretas e pessoais do SF. Mas ele também queria desafiar a História. Ele queria jogar na cara de SF que não concordava com seus métodos. Ele, em completo sigilo, dedicou sua vida e obra a prestar uma homenagem aos matemáticos judeus alemães que pereceram durante a Shoah. A maior e mais terrível armação de SF. Ato de Deus que Paul nunca aceitaria.

Durante sua vida, Paul havia estudado, e tentado resolver todos os problemas sonhados por esses jovens que foram exterminados, ou foram obrigados a se matar. Sim, a vida de Paul foi uma homenagem aos 'amigos' que pereceram: Paul Epstein, Otto Blumenthal, Friedrich Hartogs, Felix Hausdorff, Fritz Noether, Robert Remak, Ludwig Berwald, Walter Fröhlich, Kurt Grelling, Charlotte Hurwitz, Margarete Kahn, Paul Lonnerstädter, Nelli Neuman, Georg Pick, Reinhold Strassmann, Alfred Tauber. E ele foi bemsucedido. Através da sua devoção à matemática, Paul desafiou e confrontou os desígnios maléficos de SF. Desse Deus em que ele nunca de fato acreditou.

\section{5.}

Paul está eternizado. Qualquer acadêmico vivo que faça matemática possui um 'Número de Erdös' em homenagem à sua memória. Erdös possuiu o número 0 . O trivial. O inicial. Qualquer um que escreveu um artigo com ele tem número de Erdös 1. E se alguém escreveu um artigo com alguém de número 1, este possui número de Erdös 2. E assim sucessivamente. E para combater essa divindade infinita e estúpida, os números de Erdös são finitos. Pela quantidade e qualidade de artigos que ele produziu, todos os matemáticos estariam ligados a Paul por um número não superior a 7. A simplicidade e beleza que Paul sempre procurou.

Paul desapareceu em 1996, participando de um Congresso. Na noite anterior ele havia sonhado com Klára, Magda e Anna. Acordou com uma estranha felicidade. Sentiu saudades. Vontade de estar perto, e de parar de enfrentar o Criador. Ele sentiu um conforto e uma tranquilidade até então nunca experimentados. Passou o dia alegre, assobiando e pensando nos seus amados números primos. E teve uma fantástica ideia! Epifania maravilhosa! Vislumbrou o grande Livro. E finalmente encontrou o que tanto buscava. Eureka! Ninguém nunca soube, e nunca terá acesso, mas Paul, no exato instante de sua morte, resolveu “A Hipótese de Riemann”. $\mathrm{O}$ único problema que minimizava a somatória dos pontos de SF. Ele morreu com um sorriso reconfortante e satírico em seus lábios. Encontrou a vitória e o amor que tanto buscava.

Submetido em: 19/05/2015

Aprovado em: 25/08/2015 
